\title{
ALCOHOLIC PERIPHERAL NEURITIS IN ADVANCED AGE.
}

\author{
BY ARTHUR MAODE.
}

Mr. C., a robust country gentleman of sporting outdoor habits had taken stimulants to excess for certainly twenty years. There was good evidence that some eighteen years ago no unusual daily allowance was half a gallon of beer, a bottle of sherry and perhaps eight or ten liqueur glasses of neat whiskey. In spite of ample means his favourite drink was beer, and he would in his later years sit drinking beer all day, beginning at breakfast. During the summer of 1894 , when over 75 years old, he would often consume two quarts of beer, a bottle of sherry and half a bottle of whiskey in one day. This large amount of alcohol never seemed to disturb his digestion or very greatly affect his appetite; and many years ago, his relatives assert, he would sit down to dinner apparently quite drunk, eat a good meal and get up "quite sober." He never had any serious illness, except broken bones from riding accidents. He "carried his liquor" in such a remarkable way that in 1892 he fell downstairs one night going to bed, but contrived to undress himself and get to bed without discovering (as his valet did next morning) that he had broken his humerus. Excellent union resulted with no impairment of the shoulder joint (under the writer's care).

For several years he had presented increasing hebetude of mind, but not to an undue degree for his age, while his memory remained excellent when roused. Even after such a severe accident he showed no signs of delirium tremens. During the summer of 1894 his general muscular power became greatly diminished, so that he could only just stand and walk with assistance. In October, 1894, he began to complain of darting pain of a severe character over the distribution of the left posterior tibial nerve. About the middle of November the hands and feet began to swell rather suddenly, while a few weeks before there were no signs of œdema. 
December 7.-The hands are much swollen, the backs being quite tense, and shiny, the skin exceedingly thin and glossy; there is no swelling of the fingers and he can remove his rings easily. The skin of both hands is much discoloured and livid, with small, defined ecchymoses dotted over them.

The insteps of both feet present the same condition. There is cedema of calves and thighs, while the muscles are much shrunken. The face is puffy and bloated, but there is no œdema of the eyelids.

There has been some tendency to spontaneous ecchymoses for several years. He can just stand with assistance and shuffle a few steps with feet wide apart. There is, however, no definite extensor paresis. Tendon reflexes (patellar) quite absent on both sides (tested by Buzzard's method). Pupils contracted to pin points, no reaction to light or accommodation.

Urine 1,020, highly acid, dark from bile pigments, no albumen, no glycosuria.

Heart-feeble in action, regular, no sign of dilatation. Arteries soft for his age. Great dyspnca on the least exertion.

No gastric or intestinal disturbance; liver not apparently enlarged.

No hyperæsthesiæ; no pain except in the left leg and thighs. No deafness.

Can move his fingers naturally and oppose his thumbs and little fingers properly.

December 10.-Both radial pulses were of fair volume, though feeble in action.

December 11.-Both pulses were found almost impalpable, though the carotid pulse was good, and the heart sounds were not more feeble.

December 12.-The fingers of the right hand, especially the two middle ones were quite blue and livid, but not swollen. The œdema elsewhere is distinctly less, probably owing to diuretics and digitalis with strychnine that he has been taking.

December 13.-Died quite suddenly after a few moments' dyspnœa.

No post-mortem allowed.

Remarks.-The peculiar nature of the œdema and the symptoms of local asphyxia leave no room for doubt that the condition was one of peripheral neuritis. If so the case is worthy of record from the extreme age of the patient, as it is very rarely that a man with such habits survives long 
enough to manifest such symptoms at 75 . The continued habit of beer drinking bears out Dr. Ross's observation on the point ("Peripheral Neuritis," p. 150). The intensity of the vasomotor symptoms as compared with the motor disturbance is striking. Contracted fixed pupils have been noted by Fischer (Ross, " Peripheral Neuritis," p. 155).

The trophic phenomena were well marked, viz., the thin, smooth, glossy skin, and dry, brittle nails, but they were probably exaggerated by old age. About a year before death there had been an irruption of "papular eczema" limited to the extensor surfaces of both arms and the nape of the neck and interscapular regions (Ross, p. 158).

The purpuric spots are also a condition found in old age; it is noticeable that they occurred more frequently and were of larger area in the right hand, possibly because the nerve trunks of this arm had been damaged by the fracture two years before.

The absence of all distinct mental change is remarkable, but it must be remembered that this gentleman had always been in easy circumstances and for years had led the life of an absolute recluse, scarcely seeing anyone except his own servants, and for several years had never left his house and gardens. 